\title{
Theory Into Practice in Art Education: A Case Study Theresa Marché
}

Beginning as early as 1800 , the history of art education in the United States has been marked by a succession of theories delineating rationales, goals, and contents for art curricula. Art education history is a relatively new area of study and several authors have documented many of these historical trends (Belshe, 1946; Efland, 1989; Logan, 1955; Soucy, 1990). Their work primarily has concerned either beginnings of art education in America, evolution and general characterization of art education theories, or social and political climates attending each. As they were written, these accounts often gave the impression of a more or less complete implementation of a particular art education theory that was paramount at any time on an historical continuum.

However, my experience as an art teacher in the public schools made me wonder if this was actually the case. Others have written about the discrepancy between educational theory and actual classroom practice that may appear even among those who profess to follow a particular theory (Cuban, 1984; Korzenik, 1990). Rogers (1990) discussed the process by which an existing art curriculum remained essentially unchanged while being 'rewritten' in the language of a new education philosophy (p. 155). Such a process must be of concern to modern art education theorists, including those advocating the present model of discipline-based art education.

This gap between theories derived from research and actual practice of teachers in classrooms has been noted in both art and in general education curricula (Belshe, 1946; Cuban, 1984; Dewey, 1965; Eisner, 1988; Erickson, 1979). Moreover, various theoretical trends in art education have generally followed or reflected educational thinking on a wider scale (Eflan, 1990). Because classroom teachers often are responsible for teaching art as well as general curricula, problems of implementation found in art education history may prove to be relevant to a wide educational audience.

Implementation of educational innovation may be influenced by choices of staffing, ease and simplicity of comprehension, manner of presentation to teachers, political choices, social or economic conditions, sense of tradition, or personal idiosyncrasies. Erickson (1979) speculated upon the influence of inappropriate models for researchers and practitioners while Jackson (1968); pointed to a disparity in the concerns and needs of those who research and those who practice. Latham (1993) pointed to failure 
of teachers to consult educational research literature to inform their classroom practice.

If educational research is to be relevant to classroom practitioners, disparities between research and practice must be bridged. One may either emphasize the role of the researcher and remediate the practitioner, or evaluate the needs of the practitioner to inform the work of the researcher. It was the latter course that I chose when I decided to examine the art curricula from a single, suburban, middle-class school district in southeastern Pennsylvania as a case study. My objectives were to locate historical trends and influences that aided or impeded implementation of new theories in art education as they were interpreted, accepted, or rejected at the local level. In the study, I attempted to trace the process from theoretical levels, through state educational guidelines, down to the district level against a broader context of world events and general curriculum history. "The ways the visual arts are taught today were conditioned by the beliefs and values regarding art held by those who advocated its teaching in the past" (Efland 1989, p. 1).

\section{Art Education History, 1800-Present}

Much of the research on art education history in the United States has been done in the last twenty years. Before that time, most historical accounts were derived from the Bureau of Education report prepared by Clarke (1874). In the years that followed, his account was summarized and augmented as individual chapters in a number of art education texts. The first book devoted entirely to the history of art education, Growth of Art in America's Schools, was written by Logan in 1955. The decade of the 1980 's saw greater interest in the field and, along with numerous journal articles, two major books appeared, Art in American Schools in the Nineteenth Century (Wygant 1983) and, most recently, A History of Art Education (Efland 1989). Historical works by others, such as Erickson (1979), Hamblin (1984), Stankiewicz (1985), Freedman (1987), Zimmerman (1989), Korzenik (1990), and Soucy (1990) have appeared with increasing frequency in dissertations, journals and monographs in the past fifteen years.

As I reviewed this history I began to see a process that is both cyclical and linear. Efland (1990), echoing earlier writers, has identified two streams that have been flowing through art education history. In the romantic/expressive stream, the learner is central to the discovery of knowledge, while in the scientific/rational stream, subject matter, or knowledge, is at the center with the learner receiving it from outside sources. At the level of theoretical writing, a cycling of the two streams becomes most 
evident, especially after 1850 , with opinion shifting readily at about twenty year intervals, usually in response to world social and economic events.

In recent history, the romantic stream, in the form of creative selfexpression advocated by Viktor Lowenfeld (1947), was the dominant view. Almost fifty years later this theory persists in practice, although writers and theorists (Clark, Day \& Greer, 1985; Eisner, 1987) have been moving toward a more scientific/rational view. Their efforts are providing infusion of new subject matter into the rational stream that had almost disappeared at the start of the century. This has culminated in Discipline-based Art Education (DBAE), promoted by the Getty Center for Education in the Arts (1985).

All of the above, however, concern art education theory, and it is important to remember that general curriculum history is often a history of policy rather than educational practice. Art education history is no different in this respect. "If we ignore how policy is translated into practice, we ignore reality" (Rogers 1990, p. 153). To complicate matters further, there are two levels of practice: curriculum prescriptions advocated within each art educational theory, and translations of those prescriptions into action by practicing teachers.

In terms of curriculum prescriptions, art education history progresses in a more linear than cyclical fashion within each of the two streams. Chronologically, the romantic stream displays a relatively straight vector through time with some elements being added and others redefined, but not discarded. However, the rational stream shows a major discontinuity in the early twentieth century, at which time it almost disappears. For about forty years, very few rational-stream elements persist. Then, by mid-century, new theories appear that result in an infusion of new subject matter and a totally different direction than previous rational stream content.

When educational theory and curricula are translated by local teachers into actual practice, there is a great amount of eclectic borrowing and adaptation from both streams. Examination of curricula ranging from the 1899 Prang Elementary Course (Clark, Hicks \& Perry, 1899) to modern district-level programs reveals an amalgamation of art educational practices derived irom a succession of theories that were viewed as directly oppositional when first proposed.

From historical inquiry, I have gained not only a background about art curriculum development, but also a striking picture of the discrepancy between theory and practice that has marked the field of art education. Because this discrepancy between theory and practice was central to the 
present study, knowledge about the processes of adoption or rejection of innovation became a primary concern.

Within the area of educational systems analysis, much of the research on adoption of change has focused on mathematics, computers, science, and language arts. Numerous investigators have pointed to the key role of administration and central offices in successful adoption of innovation (Cox, 1983; Crandall, 1983; Huddle, 1987; Miles, 1983; Oakes \& Schneider, 1984). Educational systems thereby fit Rogers (1983) characterization as authoritative systems in which change is instituted and supported from above in a hierarchy, as opposed to being adopted in grass-roots fashion on individual bases.

Art education, however, does not fit this authoritative model very well. Certainly for high-priority subjects such as math, reading, science, and computers, educational administration at the highest level is actively involved in producing innovation. Such an authoritative model, prescribed by Getty for implementing DBAE, has been effective in those situations where the Getty Center has invested considerable resources and support. Such efforts have not been the norm, however, and for much of its history in the public schools, art has been a marginal subject that rarely, if ever, receives such attention (Efland 1989; Eisner 1987). The sole administrator with active, close, long term involvement in art programs most often is the art department chairperson or art supervisor.

Lacking an infusion of outside-in administrative direction and support, art programs often are left with inside-out, teacher initiated change that has been characterized as less effective (Cox, 1983; Crandall, 1983; Huberman, 1983; Huddle, 1987). Although Havelock (1973) provides a model of peer change agent/client interaction that often includes consultation of outside resources, the most common source of advice and support for a teacher is another teacher (Shanker, 1986).

According to Rogers (1983), if the change agent and client are too similar, no change is possible. Therefore, for change to diffuse from teacher to teacher, at least one of those individuals must be involved actively in personal growth, through such means as professional organizations or continuing education. There also must be opportunities for contact and communication among individual art department members. Given the relative isolation of art teachers from their peers, especially in elementary schools and rural areas, open communication channels become crucial if change is to be effected. 
With this inside-out, peer agent innovation model, changes tend to occur in smaller increments than the outside-in model (Rogers 1983), thus making successful adoption and institutionalization more problematic (Huberman 1983; Oakes \& Schneider, 1984). If this is the usual model of innovation for art programs there indeed may be little lasting change produced.

\section{Objectives}

Although discrepancies between theoretical and practical levels of education have been cited before, "few investigators have examined exactly what teachers have done in classrooms" (Cuban 1984). but actual classroom practice, because it most directly affects students, is an area where an historical understanding is essential. Therefore I framed the present inquiry as a case study, choosing to examine a suburban, middle-class school district in Pennsylvania where I taught for many years. During that time the art curriculum was written and rewritten several times, with varying amounts of change in practice produced. In this study, I decided to examine as broad a time period as possible for a chronology of change within that art curriculum in order to locate the source and process of adoption of any such changes.

Research for this study was conducted from September of 1992 until November of 1993, with a series of extended visits to Pennsylvania. Three types of data were collected: (1) documents from archival sources as well as public and personal sources, (2) interviews with art department chairpersons, students, art teachers and classroom teachers who are presently teaching or retired, and (3) my own personal memory and records.

\section{Data Collection and Analysis}

(1) Archival, public, and personal documents. A major source of documents was the district's central administrative office. These documents included several long-range development plans for the district that included district policy statements, program evaluations and school population statistics. Personnel records and school district directories showing the size of the art department, pre-service education, class assignments, and inservice education gave a picture of the art faculty as a whole and of individual art teachers' professional growth patterns. Because many of the district's teachers, in both general and art education, were graduates of the local college, archives from that institution were helpful in understanding teacher's pre-service educational experiences. 
Much information also was found in the personal files of selected individuals including active and retired department chairpersons, art teachers, classroom teachers and past art students. Other documents of interest examined concemed special art activities, programs or shows. School calendars since 1970 have featured student art work and were considered as well as other photographic evidence found in personal records. Past students also provided examples of work done in their art classes.

The earliest history of the district, concerning the several small schools that were consolidated to from the modern district, was derived from several locally produced area histories originally written for the 1975-76 national bicentennial celebration. State mandated programs, studies, curriculum guides, and reports were located in files of the Pennsylvania State Department of Education, Harrisburg, Pennsylvania and collections of historical materials held by individuals at Kutztown University, Kutztown, Pennsylvania. Privately held family documents in the possession of one local individual were invaluable for information about the first art teacher in the district.

(2) Interviews. While documents provided much important data, interviews with key informants guided further investigations and gave detail and depth to the record as well as presenting information from different personal points of view. Principals among these informants were two past art department chairpersons, both of whom are still in the local area and whose tenure began during the final stages of district consolidation. Several retired classroom teachers living in the local area were able to shed light on early programs. Present and past district superintendents also played an important role in providing information.

(3) Personal Memory. With twenty years of experience in this school district, my own records and memory spanned an important period of time from 1969 until 1990. Within that twenty years, the art curriculum was written and rewritten several times, both in response to local needs and statedeveloped mandates. Art program adjustments resulted indirectly from several administrative decisions .Also, within the department itself, at least one major philosophical stance was negotiated with curricular implications.

Throughout the entire process of doing this research, it has been necessary to bear in mind the subjective nature of both historical documents and of human memory (Carr, 1961; Grele, 1991; Warren, 1978). Even before the historian begins a study, most historical records have been 'selected' and culled over time, as individuals have saved documents they regarded as valuable and discarded the rest. In many instances, the historian must use

Marilyn Zurmuehlen's Working Papers.In Art Education 1994-1995 
whatever is available. In interviewing, malleability and selectivity of each person's memory must be appreciated. In addition, my own memory and assumptions will continue to play significant roles in the final form of this research. Wherever possible, findings were confirmed through multiple sources. If this was not possible, that fact also will be reported.

\section{Reporting}

This written account has been framed as a chronological narrative in four parts. First, I constructed a brief general history of the school district including that of the schools that pre-existed its formation. Indication of the local setting, both cultural and geographical, was included to facilitate an understanding of the events reported.

The largest section of this research traced development of the school district's art curriculum from 1924 until 1992 . That history was divided into three parts. In the earliest part, from 1924 to 1960, the district was a loose affiliation of township and borough school districts served by a single art teacher, whom I would characterize as a painting master. Drawing upon a nineteenth century academic art tradition, this gentleman taught oil painting to future hobby painters at the high school. During the second period, from 1960 to 1985 , two strong art administrators in succession chaired a rapidly growing art department within an expanding, consolidated, bureaucratic school district. They administered an art program based on active teacher instruction in art concepts, skills, techniques, and vocabulary, despite the contemporary nationwide popularity of Lowenfeldian creative self-expression in art education. In the final part of this history, from 1986 to 1992, without the leadership of a department chair, individual members of the art department responded to a new administrative focus on "empowerment" and from contemporary art education discourse constructed a variety of educational approaches and practices.

I am now in the process of concluding this study. I will search within this historical chronology for instances and possible sources of change, and for those forces that aided or impeded adoption of new models. In this way, 1 hope to accomplish my goal of shedding light on those means by which change was actually negotiated into this school district's art program.

Given the current emphasis on reform and restructuring in general education, and the work of the Getty Center in support of discipline-based art education, an understanding of educational change processes becomes quite valuable. But this understanding must extend beyond the adoption of official policy and reach to the level of practice, because it is at this level that

Marilyn Zurmuehlen's Working Papers In Art Education 1994-1995 
students are most directly affected. If future art educational reform efforts, including DBAE, are to be effective, we need to know how and why art teachers adopt change. It is my hope that, at completion, this study will provide insights on that area of historical inquiry in art education.

\section{References}

Belshe, F. (1946). A History of Art Education in the Public Schools of the United States. Doctoral dissertation, Yale University. Published 1975, Ann Arbor, Ml: University Microfilms.

Carr, E. H. (1961) What is History? New York:Macmillan

Clark, G., Day, M., \& Greer, D.(1985) Discipline-Based Art Education: Becoming Students of Art. Journal of Aesthetic Education, 21 (2). 129-193.

Clark, J. S., Hicks, M. D., \& Perry, W. S. (1899). The Prang Elementary Course in Art Education, Part IV, (Sixth year, books $7 \& 8$ ). New York: The Prang Educational Company.

Clarke, I. E. (1874). Drawing in Public Schools: The Present Relation of Art to Education in the United States. Bureau of Education. Circulars of Information 1874, no 2. Washington DC: Government Printing Office.

Cox, P. L. (1983). Complementary Roles irı Successful Change. Educational Leadership, 41 (3), 10-13.

Crandall, D. P. (1983). Teacher's Role in School Improvement Educational Leadership, 41 (3), 6-9.

Cuban, L. (1984). How Teachers Taught: Constancy and Change in American Classrooms 1890-1980. New York: Longman.

Dewey, J. (1965). The Relation of Theory to Practice in Education. In M. Borrowman (E.), Teacher Education in America: A Documentary History (pp. 140-171). New York: Teachers' College Press 
Efland, A. (1989). A History of Art Education: Intellectual and Social Currents in Teaching the Visual Arts. New York: Teachers College Press.

Efland, A. (1990). Art Education in the Twentieth Century: A History of Ideas. In D. Soucy \& M. Stankiewicz (Eds.), Framing the Past: Essays on Art Education (pp. 117-136). Reston, VA: National Art Education Association.

Eisner, E. (1987). The Role of Discipline-Based Art Education in America's schools. Art Education, 40 (5), 6-45.

Eisner, E. (1988). The Primacy of Experience and the Politics of Method. Educational Researcher, 17 (5), 15-20.

Erickson, M. (1979). An Historical Explanation of the Schism Between Research and Practice in Art Education. Studies in Art Education, 20 (2), 5-13.

Freedman, K. (1987) Art Education and Changing Political Agendas: An Analysis of Curriculum Concerns of the 1940s and 1950s. Studies in Art Education, $29(1), 17-29$.

Getty Center for Education in the Arts. (1985). Beyond Creating: The Place for Art in America's Schools. Los Angeles, CA: The J. Paul Getty Trust.

Grele, R. (1991). Envelopes of Sound: The Art of Oral History. New York: Praeger.

Hamblin, K. A. (1984). An Art History Chronology: A Process of Selection and interpretation. Studies in Art Education, 26 (2), 111-120.

Havelock, R. (1973). The Change Agent's Guide to Innovation in Education. Edgewood Cliffs, NJ: Educational Technology Publications.

Huberman, A. M. (1983). School Improvement Strategies That Work: Some Scenarios. Educational Leadership, 41 (3), 23-27.

Huddle, E. (1987) Ail That Glitters Isn't Gold-- Four Steps to School Improvement. NASSP Bulletin, 71 (499), 80-86.

Marilyn Zurmuehlen's Working Papers In Art Education 1994-1995 
Jackson, P. W. (1990). Life in Classrooms. New York: Teachers' College Press.

Korzenik, D. (1990). A Developmental History of Art Education. In D. Soucy \& M. Stankiewicz (Eds.), Framing the past: essays on art education (pp. 201-212). Reston, VA: National Art Education Association.

Latham, G. (1993). Do Educators Use the Literature of the Profession? NASSP Bulletin, 77 (599), 63-70.

Logan, F. M. (1955). Growth of Art in American Schools. New York: Harper \& Brothers.

Lowenfeld, V. (1947). Creative and Mental Growth. New York: MacMillan.

Miles, M. (1983). Unraveling the Mystery of Institutionalization. Educational Leadership, 41 (3), 14-19.

Oakes, J., \& Schneider, M. (1984). Computers and Schools: Another Case of "...the More They Stay the Same:? Educational Leadership, 42 (3), 73-79.

Rogers, A. W. (1990. Art Education in British Columbia Between the Wars: Official Prescription- Unofficial Policy. In D. Soucy \& M. Stankiewicz (Eds.), Framing the Past: Essays on Art Education (pp. 153-164). Reston, VA: National Art Education Association.

Rogers, E. M. (1983).Diffusion of Innovations. New York: The Free Press.

Shanker, A. (1986). Teachers Must Take Charge. Educational Leadership, 44 (1), 12-13.

Soucy, D. (1990). A History of Art Education Histories. In D. Soucy \& M. Stankiewicz (Eds.), Framing the Past: Essays on Art Education (pp. 3-31). Reston, VA: National Art Education Association. 
Stankiewicz, M. (1985). Mary Dana Hicks Prang: A Pioneer in American Art Education. In M. Stankiewicz \& E. Zimmerman (Eds.), Women Art Educators II. (pp. 22-38). Bloomington IN: Indiana University.

Warren, D. (Ed.). (1978). History, Education, and Public Policy, Berkeley, CA: McCutchan.

Wygant, F. (1983). Art in American Schools in the Nineteenth Century. Cincinnati: Interwood Press.

Zimmerman, E. (1989). The Mirror of Manie Bashkirtseff: Reflections About the Education of Women Art Students in the Nineteenth Century. Studies in Art Education, 30 (2), 164-175. 